\title{
AIP
}

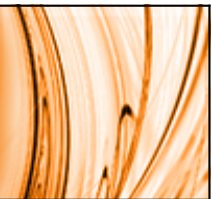

\section{Ferroelectric bismuth titanate films by hot wall metalorganic chemical vapor deposition}

Jie Si and Seshu B. Desu

Citation: Journal of Applied Physics 73, 7910 (1993); doi: 10.1063/1.353943

View online: http://dx.doi.org/10.1063/1.353943

View Table of Contents: http://scitation.aip.org/content/aip/journal/jap/73/11?ver=pdfcov

Published by the AIP Publishing

\section{Articles you may be interested in}

Atomic vapor deposition of bismuth titanate thin films

J. Appl. Phys. 113, 187207 (2013); 10.1063/1.4801985

Chemical vapor deposition of barium strontium titanate films using a single mixture of metalorganic precursors

J. Vac. Sci. Technol. A 17, 3115 (1999); 10.1116/1.582024

Ferroelectric $\mathrm{SrBi} 2 \mathrm{Ta} 2 \mathrm{O} 9$ thin film deposition at $550^{\circ} \mathrm{C}$ by plasma-enhanced metalorganic chemical vapor deposition onto a metalorganic chemical vapor deposition platinum bottom electrode J. Vac. Sci. Technol. A 17, 83 (1999); 10.1116/1.581554

Pulsed laser deposition and ferroelectric characterization of bismuth titanate films Appl. Phys. Lett. 58, 1470 (1991); 10.1063/1.105200

Epitaxial growth of ferroelectric bismuth titanate thin films by pulsed laser deposition Appl. Phys. Lett. 57, 1505 (1990); 10.1063/1.104128

MIT LINCOLN LABORATORY CAREERS

Discover the satisfaction of innovation and service to the nation

$\begin{array}{ll}\text { - Space Control } & \text { " Advanced } \\ \text { Electronics }\end{array}$

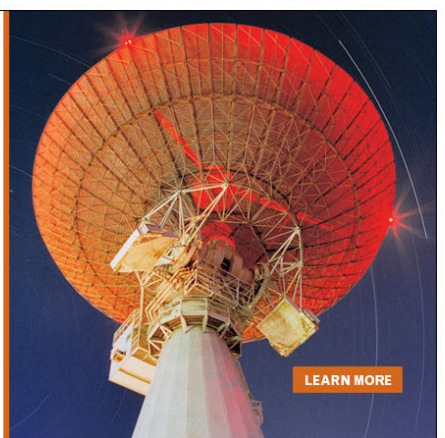




\title{
Ferroelectric bismuth titanate films by hot wall metalorganic chemical vapor deposition
}

\author{
Jie Si and Seshu B. Desua) \\ Department of Materials Science Engineering, Virginia Polytechnic Institute and State University, \\ Blacksburg, Virginia 24061
}

(Received 9 September 1992; accepted for publication 18 February 1993)

\begin{abstract}
Ferroelectric bismuth titanate thin films were successfully deposited on Si, sapphire disks, and $\mathrm{Pt} / \mathrm{Ti} / \mathrm{SiO}_{2} / \mathrm{Si}$ substrates by hot wall metalorganic chemical vapor deposition. Triphenyl bismuth $\left[\mathrm{Bi}\left(\mathrm{C}_{6} \mathrm{H}_{5}\right)_{3}\right]$ and titanium ethoxide $\left[\mathrm{Ti}\left(\mathrm{C}_{2} \mathrm{H}_{5} \mathrm{O}\right)_{4}\right]$ were used as the precursors. The deposition rates were in the range of 3.9-12.5 nm/min. The $\mathrm{Bi} / \mathrm{Ti}$ ratio was easily controlled by precursor temperature, carrier gas flow rate, and deposition temperature. As-deposited films were pure $\mathrm{Bi}_{4} \mathrm{Ti}_{3} \mathrm{O}_{12}$ phase. The films were specular and showed uniform and fine grain size. Optical constants as a function of wavelength were calculated from the film transmission characteristics in the ultraviolet-visible-near infrared (UV-VIS-NIR) region. The $550^{\circ} \mathrm{C}$ annealed film showed a spontaneous polarization of $26.5 \mu \mathrm{C} / \mathrm{cm}^{2}$ and a coercive field of 244.3 $\mathrm{kV} / \mathrm{cm}$.
\end{abstract}

\section{INTRODUCTION}

Bismuth titanate $\left(\mathrm{Bi}_{4} \mathrm{Ti}_{3} \mathrm{O}_{12}\right)$ is one of the few important ferroelectric materials. This compound has a high $\mathrm{Cu}$ rie temperature of $675^{\circ} \mathrm{C}$. In a single crystal, there are two polarization axes: the major one, with $P_{s}=50 \mu \mathrm{C} / \mathrm{cm}^{2}$, along the $a$ axis of the (pseudo-)orthorhombic structure, while the minor polarization axis, with $P_{s}=4 \mu \mathrm{C} / \mathrm{cm}^{2}$, along the $c$ axis. The coercive fields are 50 and $3-5 \mathrm{kV} / \mathrm{cm}$ for $a$ and $c$ axes, respectively. ${ }^{1} \mathrm{Bi}_{4} \mathrm{Ti}_{3} \mathrm{O}_{12}$ also has a unique rotation of the optical indicatrix upon polarization switching. ${ }^{2}$ These interesting properties have enabled a variety of applications. A ferroelectric field-effect memory device using $\mathrm{Bi}_{4} \mathrm{Ti}_{3} \mathrm{O}_{12}$ thin film has been reported. ${ }^{3}$ It has been also considered as an alternate ferroelectric material for ferroelectric random access memories (FRAMs) and dynamic random access memories (DRAMs). $\mathrm{Bi}_{4} \mathrm{Ti}_{3} \mathrm{O}_{12}$ thin films formed on a superconducting $\mathrm{Bi}_{2} \mathrm{Sr}_{2} \mathrm{CaCuO}_{6+x}$ bottom electrode showed promising ferroelectric properties, as well as good radiation hardness, excellent aging characteristics, and the potential for integration into semiconductor device processing technology. ${ }^{4}$ In addition, modulator and display applications of $\mathrm{Bi}_{4} \mathrm{Ti}_{3} \mathrm{O}_{12}$ have also been evaluated. ${ }^{2}$

$\mathrm{Bi}_{4} \mathrm{Ti}_{3} \mathrm{O}_{12}$ thin films have been prepared by rf sputtering, ${ }^{2}$ pulsed laser ablation, ${ }^{5,6}$ sol-gel processing, ${ }^{7}$ and metalorganic chemical vapor deposition (MOCVD). ${ }^{8}$ Among these techniques, MOCVD allows high deposition rate, excellent step coverage, and easy composition control, which are compatible with large scale processing. Miyajima et al. reported MOCVD $\mathrm{Bi}_{4} \mathrm{Ti}_{3} \mathrm{O}_{12}$ thin films on a heated substrate at $750{ }^{\circ} \mathrm{C}$ by a cold wall type reactor. ${ }^{8}$ To allow large scale processing and mass production, a low processing temperature and a hot wall type reactor are desirable. In this article, we report on the structure and composition of the hot wall MOCVD $\mathrm{Bi}_{4} \mathrm{Ti}_{3} \mathrm{O}_{12}$ thin films using $\mathrm{Bi}\left(\mathrm{C}_{6} \mathrm{H}_{5}\right)_{3}$ and $\mathrm{Ti}\left(\mathrm{C}_{2} \mathrm{H}_{5} \mathrm{O}\right)_{4}$ as precursors, as well as their optical and ferroelectric properties.

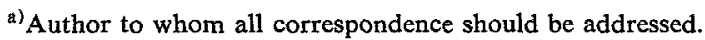

\section{EXPERIMENTAL PROCEDURE}

$\mathrm{Bi}_{4} \mathrm{Ti}_{3} \mathrm{O}_{12}$ thin films were deposited in a MOCVD apparatus that is shown in Fig. 1. $\mathrm{Bi}\left(\mathrm{C}_{6} \mathrm{H}_{5}\right)_{3}$ and $\mathrm{Ti}\left(\mathrm{C}_{2} \mathrm{H}_{5} \mathrm{O}\right)_{4}$ were used as the precursors. The precursors were kept at desired temperatures within $1{ }^{\circ} \mathrm{C}$ accuracy and carried by nitrogen gas into the reactor during deposition. Source temperatures in the range of $165-170^{\circ} \mathrm{C}$ for $\mathrm{Bi}\left(\mathrm{C}_{6} \mathrm{H}_{5}\right)_{3}$ and $75-120^{\circ} \mathrm{C}$ for $\mathrm{Ti}\left(\mathrm{C}_{2} \mathrm{H}_{5} \mathrm{O}\right)_{4}$ were employed to obtain desirable vapor pressures for this study. Pure oxygen was used as a dilute gas. Depositions were carried out at reduced pressures ( 6 Torr). Substrate temperatures were varied from 450 to $500^{\circ} \mathrm{C}$. The typical deposition conditions are listed in Table $\mathrm{I}$.

The identification of $\mathrm{Bi}_{4} \mathrm{Ti}_{3} \mathrm{O}_{12}$ phases were carried out by an $\mathrm{x}$-ray diffractometer with $\mathrm{Cu} K \alpha$ radiation. The composition of the films was investigated using energy dispersive spectroscopy (EDS). Scanning electron microscopy (SEM) was used to study the surface morphology of the films. Film thicknesses, refractive indices $(n)$, and extinction coefficients $(k)$ were obtained from ultraviolet-visiblenear infrared (UV-VIS-NIR) transmission measurements.

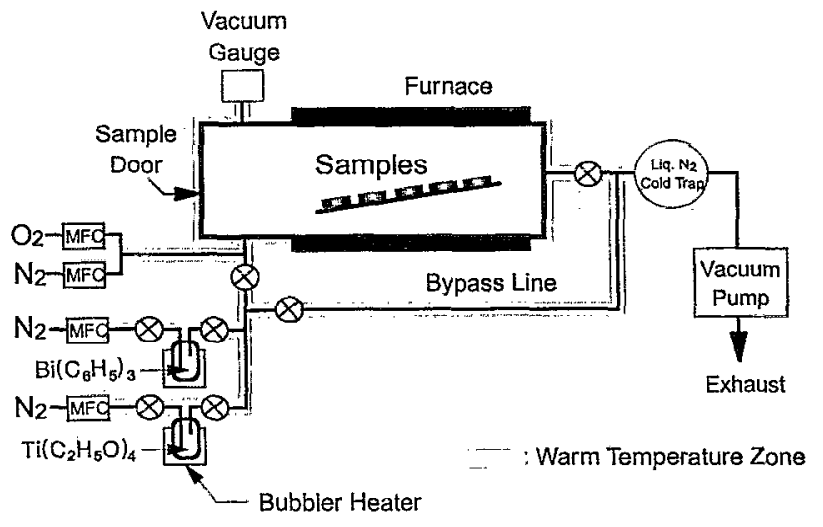

FIG. 1. Schematic diagram of apparatus for MOCVD $\mathrm{Bi}_{4} \mathrm{Ti}_{3} \mathrm{O}_{12}$ thin films. 
TABLE I. Typical deposition conditions for MOCVD $\mathrm{Bi}_{4} \mathrm{Ti}_{3} \mathrm{O}_{12}$ thin films.

\begin{tabular}{lcc}
\hline \hline Precursors & $\mathrm{Bi}\left(\mathrm{C}_{5} \mathrm{H}_{6}\right)_{3}$ & $\mathrm{Ti}\left(\mathrm{C}_{2} \mathrm{H}_{5} \mathrm{O}\right)_{4}$ \\
\hline Precursors temp. $\left({ }^{\circ} \mathrm{C}\right)$ & $165-170$ & $75-127$ \\
Carrier gas $\left(\mathrm{sccm}, \mathrm{N}_{2}\right)$ & $30-50$ & $0-8$ \\
& & \\
Substrate & Sapphire, $\mathrm{Pt} / \mathrm{Ti} / \mathrm{SiO}_{2} / \mathrm{Si}, \mathrm{Si}$ \\
\hline Substrate temp. $\left({ }^{\circ} \mathrm{C}\right)$ & $450-500$ \\
Dilute gas (sccm, $\left.\mathrm{O}_{2} \& \mathrm{~N}_{2}\right)$ & 650 \\
Total pressure (Torr) & 6 \\
\hline \hline
\end{tabular}

For the ferroelectric property measurement, $\mathrm{Bi}_{4} \mathrm{Ti}_{3} \mathrm{O}_{12}$ film was deposited on a $\mathrm{Pt} / \mathrm{Ti} / \mathrm{SiO}_{2} / \mathrm{Si}$ substrate and contacted with $2.14 \times 10^{-4} \mathrm{~cm}^{2}$ palladium as top electrodes. A Sawyer-Tower circuit at $60 \mathrm{~Hz}$ was used to measure the ferroelectric properties.

\section{RESULTS AND DISCUSSION}

For the conditions described in Table I, film growth rates were typically in the range of $3.9-12.5 \mathrm{~nm} / \mathrm{min}$. In the range of experimental parameters investigated, source temperature, substrate temperature, and carrier gas flow rate were found to have significant effect on the film composition. Figure 2 shows the variation of the composition with the source temperature of $\operatorname{Ti}\left(\mathrm{C}_{2} \mathrm{H}_{5} \mathrm{O}\right)_{4}$ and carrier gas flow rate of $\mathrm{Bi}\left(\mathrm{C}_{6} \mathrm{H}_{5}\right)_{3}$, at fixed source temperature of $\mathrm{Bi}\left(\mathrm{C}_{6} \mathrm{H}_{5}\right)_{3}$ and no carrier gas for $\mathrm{Ti}\left(\mathrm{C}_{2} \mathrm{H}_{5} \mathrm{O}\right)_{4}$. The $\mathrm{Bi} / \mathrm{Ti}$ ratio increased with the increasing carrier gas flow rate and the decreasing source temperature. The variation of $\mathrm{Bi} / \mathrm{Ti}$ ratio with substrate temperature was also studied. It was found that $\mathrm{Bi} / \mathrm{Ti}$ ratio dropped considerably at a substrate temperature of $450^{\circ} \mathrm{C}$, as shown in Fig. 3. In this study, the stoichiometry of the films were mainly controlled by varying the individual precursor temperature and the carrier gas flow rate, and the desired $\mathrm{Bi} / \mathrm{Ti}$ ratio was achieved by optimizing the processing parameters.

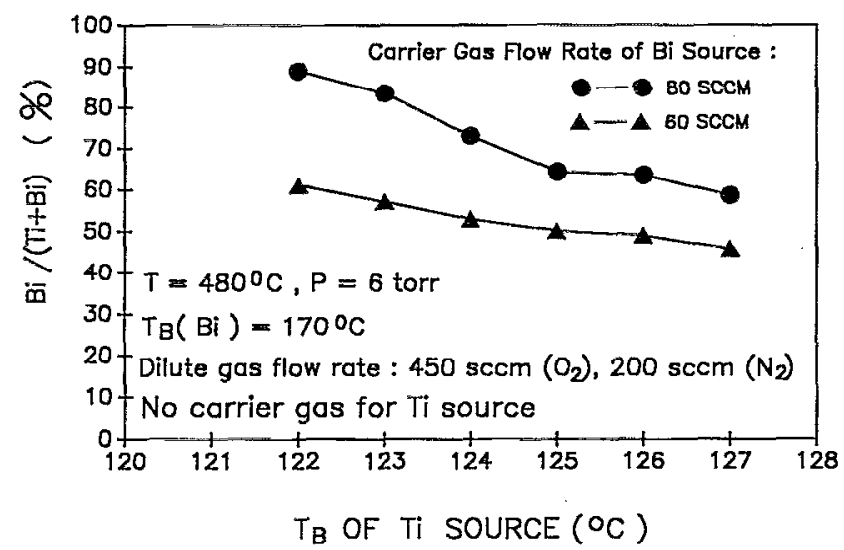

FIG. 2. Variation of thin film composition with source temperature and carrier gas flow rate.

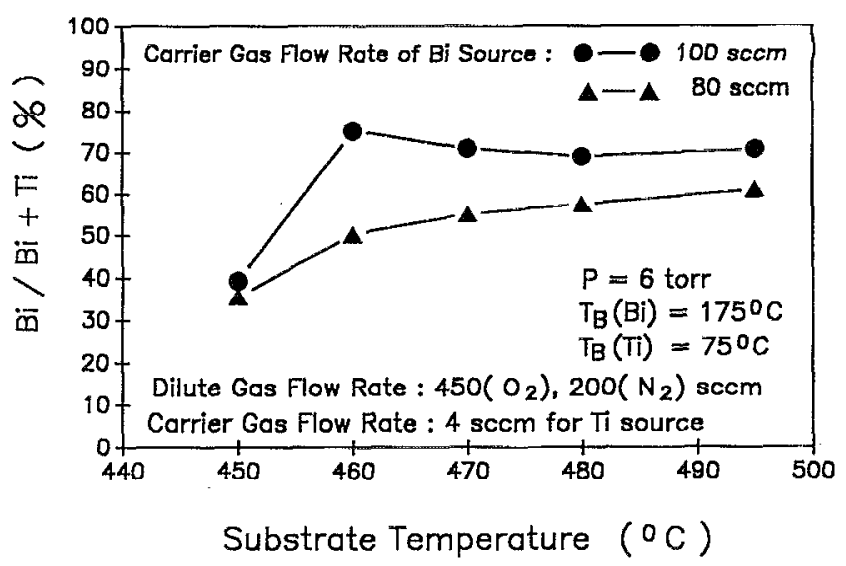

FIG. 3. Variation of thin film composition with substrate temperature.

Both as-deposited and annealed MOCVD $\mathrm{Bi}_{4} \mathrm{Ti}_{3} \mathrm{O}_{12}$ films were specular, crack-free, uniform, adhered well on $\mathrm{Si}$, sapphire, and $\mathrm{Pt} / \mathrm{Ti} / \mathrm{SiO}_{2} / \mathrm{Si}$ substrates, and were highly transparent on sapphire substrate. The surface morphologies of the annealed films were investigated by SEM, and were shown in Fig. 4. The SEM micrographs showed that the films were dense and smooth on all substrates. The grains were very fine and uniformly distributed. The average grain size was estimated to be around $0.1 \mu \mathrm{m}$.

The stoichiometric MOCVD $\mathrm{Bi}_{4} \mathrm{Ti}_{3} \mathrm{O}_{12}$ thin film prepared on Si substrate was used for structure study. Figure 5 displays the $\mathrm{x}$-ray diffraction (XRD) patterns for the $\mathrm{Bi}_{4} \mathrm{Ti}_{3} \mathrm{O}_{12}$ film at different post-deposition annealing temperatures. $\mathrm{Bi}_{4} \mathrm{Ti}_{3} \mathrm{O}_{12}$ phase was observed in the asdeposited thin film. Crystallinity was improved as the annealing temperature was increased. The XRD patterns also
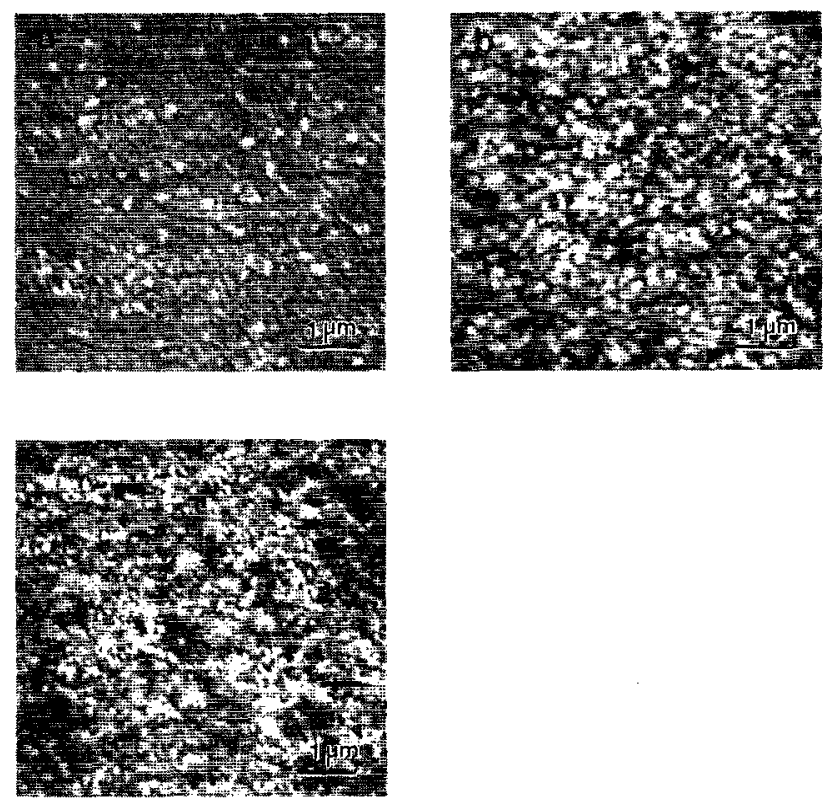

FIG. 4. SEM micrographs of MOCVD $\mathrm{Bi}_{4} \mathrm{Ti}_{3} \mathrm{O}_{12}$ thin film annealed at $550^{\circ} \mathrm{C}$ : (a) on $\mathrm{Si}$, (b) on $\mathrm{Pt} / \mathrm{Ti} / \mathrm{SiO}_{2} / \mathrm{Si}$, (c) on sapphire substrates. 


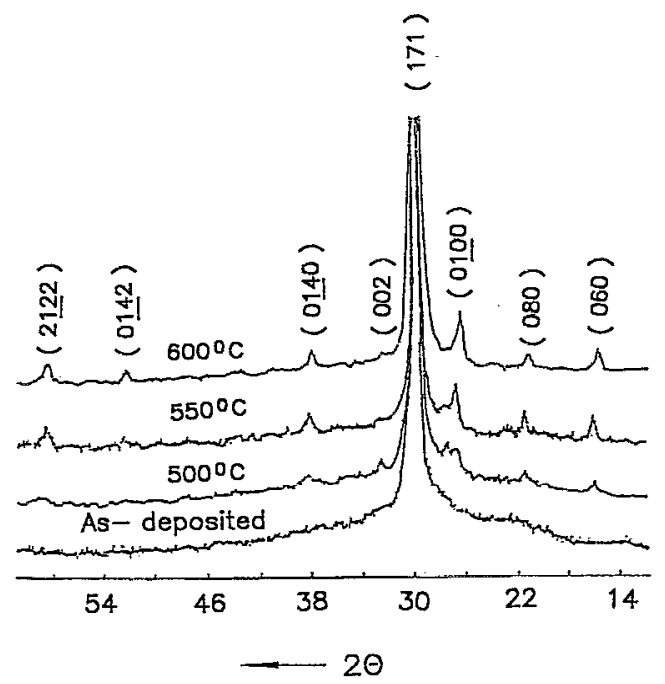

FIG. 5. X-ray diffraction patterns of the $\mathrm{Bi}_{4} \mathrm{Ti}_{3} \mathrm{O}_{12}$ film at different postdeposition annealing temperature.

revealed that good crystalline films were obtained with no secondary phases and no preferred orientation, even at annealing temperatures as low as $550^{\circ} \mathrm{C}$.

The Auger electron spectroscopy (AES) depth profile of the annealed MOCVD $\mathrm{Bi}_{4} \mathrm{Ti}_{3} \mathrm{O}_{12}$ film on $\mathrm{Pt} / \mathrm{Ti} / \mathrm{SiO}_{2} / \mathrm{Si}$ is shown in Fig. 6. The composition of the film was uniform except the $\mathrm{Bi}$ content decreased and the $\mathrm{Ti}$ content increased at the film/substrate interface.

Figure 7 shows the typical $D-E$ hysteresis loop of the MOCVD $\mathrm{Bi}_{4} \mathrm{Ti}_{3} \mathrm{O}_{12}$ film on $\mathrm{Pt} / \mathrm{Ti} / \mathrm{SiO}_{2} / \mathrm{Si}$ substrate. The film was annealed at $550^{\circ} \mathrm{C}$ for one hour to obtain good crystallinity. The $\mathrm{Bi} / \mathrm{Ti}$ ratio of the film was $57 / 43$ by EDS measurement. The spontaneous polarization $P_{s}$, remnant polarization $P_{r}$, and coercive field $E_{c}$ had values of 26.5 $\mu \mathrm{C} / \mathrm{cm}^{2}$ and $19.6 \mu \mathrm{C} / \mathrm{cm}^{2}, 244.3 \mathrm{kV} / \mathrm{cm}$, respectively.

The UV-VIS-NIR transmission and reflectance spectra of the MOCVD $\mathrm{Bi}_{4} \mathrm{Ti}_{3} \mathrm{O}_{12}$ film on the sapphire substrate is shown in Fig. 8. The transmission spectrum illustrates that the transmittance drops to $0 \%$ (the absorption edge) at

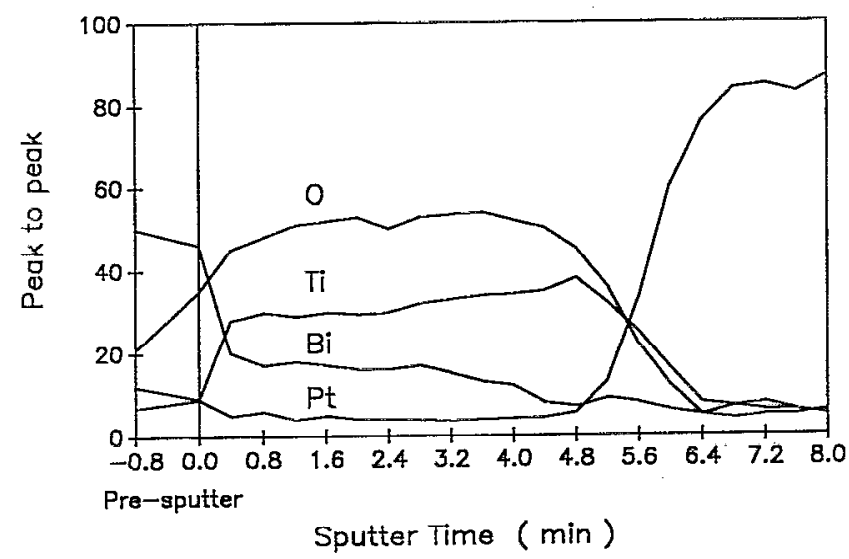

FIG. 6. AES depth profile of $550^{\circ} \mathrm{C}$ annealed $\mathrm{MOCVD} \mathrm{Bi}_{4} \mathrm{Ti}_{3} \mathrm{O}_{12}$ film.

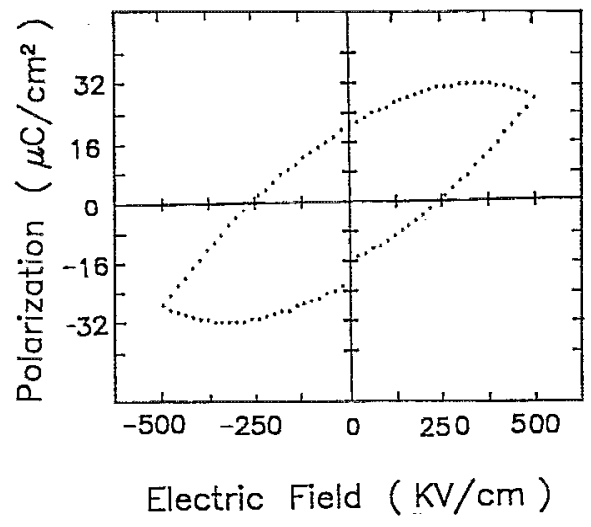

FIG. 7. Typical $D-E$ hysteresis loop of $\mathrm{MOCVD} \mathrm{Bi}_{4} \mathrm{Ti}_{3} \mathrm{O}_{12}$ film.

$\lambda=338 \mathrm{~nm}$ and has a value of $64 \%$ at $\lambda=2000 \mathrm{~nm}$. An envelope method was used to calculate the film thickness as well as the refractive index, and extinction coefficient of the film as a function of wavelength. The film thickness calculated using this method is $752 \mathrm{~nm}$. The $n$ and $k$ values were 2.507 and $2.88 \times 10^{-3}$, respectively, at $\lambda=633 \mathrm{~nm}$. The high refractive index value, compared to the value of 2.33 from sol-gel films, ${ }^{7}$ indicates the $\mathrm{Bi}_{4} \mathrm{Ti}_{3} \mathrm{O}_{12}$ film is dense. The very low extinction coefficient illustrates the nature of the specular and highly transparent film. The $n$ and $k$ as a function of wavelength are shown in Fig. 9.

\section{SUMMARY}

Crystalline $\mathrm{Bi}_{4} \mathrm{Ti}_{3} \mathrm{O}_{12}$ thin films were successfully and reproducibly fabricated at low temperature $\left(470^{\circ} \mathrm{C}\right)$ on $\mathrm{Si}$, sapphire, and $\mathrm{Pt} / \mathrm{Ti} / \mathrm{SiO}_{2} / \mathrm{Si}$ substrates by an optimized MOCVD process. The $\mathrm{Bi} / \mathrm{Ti}$ ratios of the films were con-

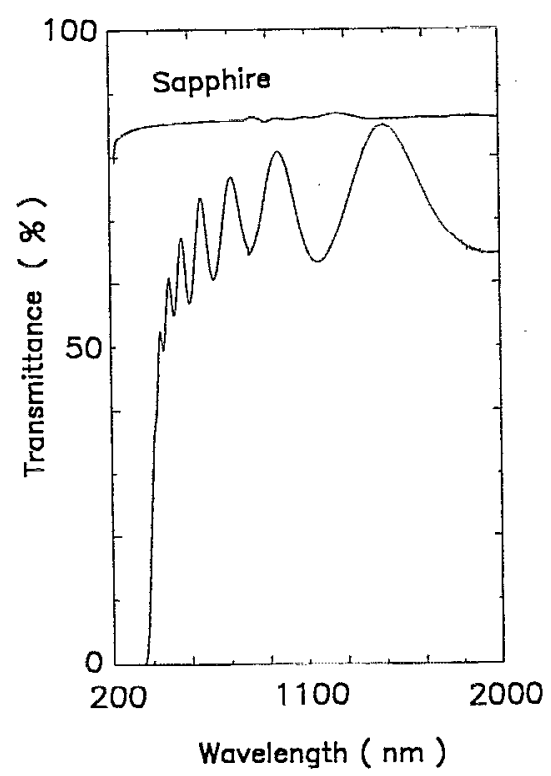

FIG. 8. Optical transmission and reflection spectrum of MOCVD $\mathrm{Bi}_{4} \mathrm{Ti}_{3} \mathrm{O}_{12}$ film on sapphire substrate. 


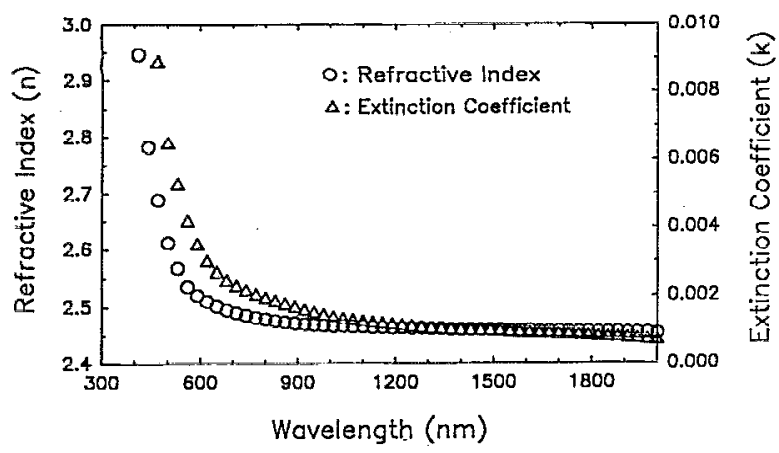

FIG. 9. Variation of refractive index and extinction coefficient of MOCVD $\mathrm{Bi}_{4} \mathrm{Ti}_{3} \mathrm{O}_{12}$ film with wavelength.

trolled by varying the MOCVD parameters, namely precursor temperature, carrier gas flow rate, and deposition temperature. The electron spectroscopy for chemical analysis (ESCA) spectrum showed no carbon contamination in the bulk of the film. A high refractive index (2.507) was obtained at $\lambda=633 \mathrm{~nm}$ in the $550^{\circ} \mathrm{C}$ annealed film. Very fine grains were observed for the films on all three different substrates used. The $D-E$ hysteresis loop was observed with the ferroelectric properties of $P_{s}=26.5 \mu \mathrm{C} / \mathrm{cm}^{2}, P_{r}$ $=19.6 \mu \mathrm{C} / \mathrm{cm}^{2}$, and $E_{c}=244.3 \mathrm{kV} / \mathrm{cm}$.

\section{ACKNOWLEDGMENTS}

We wish to acknowledge the support of DARPA through a project from ONR to this study. This work was also partially supported by Center for Advanced Ceramic Materials, the Virginia Center for Innovative Technology.

${ }^{1}$ R. Ramesh, K. Luther, B. Wilkens, D. L. Hart, E. Wang, and J. M. Tarascon, Appl. Phys. Lett. 57, 1505 (1990).

${ }^{2}$ S. Y. Wu, W. J. Takei, and M. H. Francombe, Appl. Phys. Lett. 22, 26 (1973).

${ }^{3}$ K. Sugibuchi, Y. Kurogi, and N. Endo, J. Appl. Phys. 46, 2877 (1975). ${ }^{4}$ R. Ramesh, A. Inam, W. K. Chan, B. Wilkens, K. Myers, K. Temschnig, D. L. Hart, and J. M. Tarascon, Science 252, 944 (1991).

${ }^{5}$ N. Maffei and S. B. Krupanidhi, Appl. Phys. Lett. 60, 781 (1992).

${ }^{6}$ H. Buhay, S. Singaroy, W. H. Kasne, and M. H. Francombe, Appl. Phys. Lett. 58, 1470 (1991).

${ }^{7}$ P. C. Joshi and Abhai Mansingh, Appl. Phys. Lett. 59, 2389 (1991).

${ }^{8}$ M. Miyajima, R. Muhannet, and M. Okada, J. Chem. Soc. Jpn. 10, 1378 (1991). 